\title{
A LEVINASIAN ETHICS OF ATTENTION
}

\author{
Michael Marder* \\ Duquesne University
}

In his rather fragmentary theory of attention, Emmanuel Levinas draws inspiration from phenomenology, while endeavoring to furnish it with an ethical foundation. On the one hand, he assigns to attention a crucial role coextensive with intentionality (the idea that, in each case, consciousness is conscious of, or directed toward, something). On the other hand, he mobilizes the methodology of reduction for the purpose of uncovering an ethical substratum of experience in the relation to the Other, which is deeper still than the life of consciousness it animates. Husserlian reduction is not radical enough for Levinas's philosophical taste, since it fails to recognize that this life comes into being thanks to the appeal emanating from the Other, whose calling out to me forces me to pay attention, even when it seems that I am attending only to inanimate things. The ethical relation to the Other lies not only at the bottom of all social and political structures, but also at the source of consciousness and of its attentive directedness to that of which it is conscious. Before 1 am able to intend or to attend to anything whatsoever, I am targeted by the Other, who reverses the movement of intentionality and, at once, breaches and founds my psychic interiority.

An astute interpreter of Husserl, Levinas recognizes in attention a "subjective modification" of intentionality. According to The Theory of Intuition in Husserl's Phenomenology, attention

is not a distinct type of act, as perception is distinct from will, but is a possible mode of all acts [...] Within each type of intentionality, attention expresses the

* Assistant Professor, Department of Philosophy \& FCT Research Fellow. Centro de Filosofia, University of L,isbon (marderm@duq.edu or michael.marder@gmail.com).

Phainomenon, n. ${ }^{\circ}$ 18-19, Lishoa, pp. 27-40.

DOI: 10.2478/phainomenon-2009-0002

(C) 2009 Marder. This is an open access article licensed under the Creative Commons Attribution-

NonCommercial-NoDerivs License (http://creativecommons.org/licenses/by-nc-nd/3.0/). 
manner in which the ego relates to its object. In the act of attention the ego lives actively; it is in some manner spontaneous and free. ${ }^{1}$

It is worth mentioning that the title of the chapter in which this passage appears is "The Phenomenological Theory of Being: The Intentionality of Consciousness," and attention lies at the core of the being of consciousness, or intentionality. As the "possible mode of all acts" and the "manner in which the ego relates to its object," it expresses the how of intentionality, its concrete way of operating. As soon as an act of consciousness orients itself toward something, it cannot help but attend to its target, be it the perceived, the desired, or the willed. This is what Levinas means when he calls attention a "subjective modification" of intentionality, always already singularized in tandem with its specific target.

Totality and Infinity reaffirms this initial commitment to the scope of the act of paying attention that, in its breadth, rivals intentionality:

Attention and the explicit thought it makes possible are not a refinement of consciousness, but consciousness itself [L'attention et la pensée explicite qu'elle rend possible, sont la conscience même et non point un affinement de la conscience]. ${ }^{2}$

The copula binding together the subject and the predicate in this sentence is a tribute to Husserl's general and "unitary" theory with its refusal to accept as valid the common-sense understanding of attention in terms of the hypersensitivity of consciousness, or in terms of its a posteriori selectivity. Rather, attention is the condition of possibility for explicit thought - its animating, enlivening factor - and, at the same time, conscious life itself. If, conversely, to stop paying attention to an object is to cease being conscious of it, then phenomenology discloses the life of consciousness in all its finitude, since it is impossible to attend to the same entity for an indefinite stretch of time. The modulations and shifts of attention, thus, make explicit the singularity and dynamism of phenomenological consciousness, understood as an intentional directedness-toward...

Thus far, Levinas has only restated his hermeneutical position vis-à-vis Husserl's phenomenology of attention. This avowal notwithstanding, he departs from the letter, if not from the spirit of his predecessor's philosophy in spelling out the meaning of attentive psychic life. But, despite their parting of ways, there is no complete disagreement between the two thinkers: just as Husserl believes that, in the attentive attitude, the ego does not come detached from the

1 Levinas, Emmanuel, The Theory of Intuition in Husserl's Phenomenology, trans. A. Orianne, $2^{\text {nd }}$ ed. (Evanston: Northwestern University Press, 1995), p. 46.

${ }^{2}$ Levinas, Emmanuel, Totality and Infinity: An Essay on Exteriority, trans. A. Lingis (Pittsburgh: Duquesne University Press, 1969), p. 99. 
rays of intentionality it sends to its surrounding world, ${ }^{3}$ so Levinas subscribes to the view that associates attention and the being-in-attendance (indeed, the presence) of a speaking being at the site of the production and manifestation of speech. ${ }^{4}$ Paying attention to Others, we accompany them, linger with them, and, thereby, assume our responsibility before them, repudiating the urge of self-dissimulation; the one who attends is in attendance at the site of one's concern. The link between presence and life, awaiting the advent of Derrida's reading of Husserl and the deconstructive foregrounding of writing, remains undisturbed. What does undergo a drastic alteration, however, is the monadological view of the life of the ego that fundamentally attends only to itself even when its regard is directed to the surrounding world. I wish to isolate two features of this alteration: the constitutive breach (the origin) of interiority and the ultimate recipient (the final destination) of the attentive comportment.

Levinas supplements the nod of approval he has given to the Husserlian broadening of the scope of attention with a double rejoinder:

But the eminently sovereign attention in me is what essentially responds to an appeal. Attention is attention to something because it is attention to someone [L'attention est attention à quelque chose, parce qu'elle est attention à quelqu'un]. The exteriority of its point of departure is essential to it: it is the very tension of the $\mathrm{I}^{5}$

First, my attention and the conscious life it animates are constituted in response to the appeal of the Other, which arises outside of me. Given that, in his earlier interpretive work, Levinas has performed a reading of intentionality as the self-transcendence of consciousness driven outside of itself by that of which it is, in each case, conscious, the extension of the same argument to attention should not come as a surprise. If the act of attending is the act of intending, then the former revolves around the axis of transcendence to the same extent as the latter. The breach of my interiority by an external call that demands an attentive heeding constitutes this interiority as mine and as "eminently sovereign." The entire sphere of my psychic life is attuned to, as well as convoked by, alterity, which is at the source of "the very tension of the I." The freedom and the spontaneity I seem to have exercised when selecting the objects of my attention in a sovereign manner arise only subsequently, in response to the originary appeal of the Other, who dispenses to me my freedom. The "tension of the I" that reaches a crescendo in attention is the knot of autonomy and heteronomy, freedom and responsibility, at the heart of psychic life.

${ }^{3}$ Husserl, Edmund, Ideas Pertaining to a Pure Phenomenology and to a Phenomenological Philosophy, First Book. trans. F. Kersten (Dordrecht: Kluwer Academic Publishers, 1983), p. 223.

4 Levinas, Emmanuel, Totality and Infinity, cit., p. 98.

5 Ibid., p. 99. 
Second, the interface of attention and conscious life is sustained by a reduction of the recipient of attentive comportment to the "whoness" of the other person. Now, the emphasis on the "who" in relation to the alterity of the Other is a recurrent theme of Totality and Infinity, where Levinas writes:

To the question who? answers the non-qualifiable presence of an existent who presents himself without reference to anything, and yet distinguishes himself from every other existent. The question who? envisages a face [vise un visage: literally, 'aims at the face', MM].

When I attend to something, I do so, in the last instance, for the sake of someone, for the Other, who both founds my attentional comportment and overflows any determinate representation I might form. (For instance, in attending to a broken chair, I pay attention to someone who will sit on it, since I wish to prevent his or her fall; in attending to the words I am putting down on this page, I ultimately "keep in mind" my readers and the need of facilitating their comprehension of the meaning these words carry, etc.) The implication of this Levinasian axiom is that, stripped of the capacity to reduce the "what" of attention to the founding "who," psychic life itself will ossify due to the absorption of intentionality in the lifeless contents of what it aims at. And, conversely, to pay attention to the acts of attention is already to trace them to their ultimate recipient, namely the Other: these presumably meta-theoretical concerns prove to be ethical through and through. It is important to realize that such reduction ad alterum is a task as infinite as the responsibility I assume before the Other, because the "ultimate recipient" can never be reached, that is to say, the absolute fulfillment of an attentive intuition is impossible. It is as though, by adding a deeper level of "whoness" to all acts of paying attention, Levinas interposes something particularly groundless (indeed, abyssal) in place of the concrete "things themselves", toward which traditional phenomenology always strives. I term this philosophical move "reduction to the ethical."

Reduction to the ethical, extending the trajectory of attention from inanimate entities to the Other, awakens "a life that self-evidence absorbed and caused to be forgotten." 7 How should we understand the meaning of this forgotten life? The unarticulated presupposition, guiding Levinas's critique of the absorption of life in self-evidence, is that the objective "what" to which we attend is dead and that, moreover, our failure to make a transition to the one for the sake of whom attention is paid threatens to deaden our psychic life as well-vicariously, as it were. In keeping with these assumptions, he likens that with which the subject is mesmerized to the gaze of the Medusa which, in its

${ }^{6}$ Ibid., p. 177.

${ }^{7}$ Levinas, Emmanuel, Discovering Existence with Husserl, trans. R. Cohen and M.B. Smith (Evanston: Northwestern University Press, 1998), p. 156. 
undying vigilance, extinguishes subjective life, turning those who glance at her into stone:

It is as if the self-evidence of the world as a state in which reason is contained paralyzed, Medusa-like, and petrified the reasonable life that lives that selfevidence! ${ }^{8}$

The eternal and anonymous vigilance of the real is not equivalent to attention, which is always finite, lively, and modulated. The "reasonable life" that attempts to model itself after the thingly gaze of the Medusa, or that, in Heidegger's terms, treats human existence as though it were only present-to-hand, is on the verge of committing suicide. Ethical reduction, in turn, entails a patient and open-ended work of reanimation or re-activation, incessantly pointing toward the "who" buried underneath the "what", attending, at the limit of attention, to what self-evidence conceals in its pure presence and sheer luminosity.

In what follows we will have an occasion to question some of these problematic assumptions regarding (1) the nature of "self-evidence" or, more generally, of thinghood unequivocally identified with a dead "whatness" and (2) the ability to attend to the Other without taking into account the exigencies of objectification. In both cases, a careful adumbration of the ethics of attention will be required: it will be necessary, on the one hand, to narrow down its scope in relation to the Other, who turns into its object and whose alterity is, thus, violated, and, on the other hand, to broaden its scope so as to include things considered to be inanimate under its umbrella. Suffice it to say, for now, that Levinas has overlooked the gendered content of the myth of the Medusa, noted, for instance, by Hélène Cixous in "The Laugh of the Medusa". Medusa is, precisely, neither an object nor a subject; suspended between a "who" and a "what", her head inflects living attention with death, or as Derrida writes, in a different context,

living attention here comes to tear itself toward that which, or the one who, can no longer receive it; it rushes toward the impossible. ${ }^{\text {}}$

In light of this indeterminacy, what if attention itself is inherently divided, falling neither on the side of psychic life nor on the side of death, proper neither to the "who" nor to the "what"? Though it is, certainly, not to be confused with undying vigilance, there is always a chance that it would slide into immobility if it remains excessively fixed or fixated on its object. Levinas himself recognizes

${ }^{8}$ Levinas, Emmanuel, "Philosophy and Awakening", in Entre Nous: On Thinking-of-the-Other, trans. M.B. Smith and B. Harshav (New York: Columbia University Press, 1998), p. 82.

${ }^{9}$ Derrida, Jacques, The Work of Mourning, trans. P.-A. Brault and M. Naas (Chicago and London: University of Chicago Press, 2001), p. 45, emphasis added. 
that what he has condemned as psychic death, namely the absorption of thinking in self-evidence, is, itself, a kind of life of reason ("that lives that self evidence"). Similarly, in Freud's theoretical sketch, dedicated to the myth of the Medusa, the moment of the spectator's death following the crossing of the living gaze and the dead stare is a part of psychic life, in that the stiffness of the spectator emulates the very erection that is threatened in castration anxiety, which the uncanny sight of the decapitated head both provokes and expresses. ${ }^{10}$

Levinas's reductive dream of awakening the life that self-evidence absorbed, for which the myth of the Medusa serves as a heuristic device, needs to be set in the context of the ethics of attention. When "it is a question of descending from the entity illuminated in self-evidence toward the subject," 11 then the reductive operations of probing below the level of phenomenality are not at all different from transcendence toward the Other. The descent from self-evidence carries the infinite movement of attention on to the exteriority of the other person. This is entirely consistent with Husserl's description of attention in Ideas I as piercing through the different strata of consciousness, be they purely perceptual, or remembering, or otherwise. Levinas, in turn, adds the unreachable "stratum" of absolute alterity, to which, at bottom, attention is always directed without ever attaining fulfilment in it. While, in its phenomenal luminosity, objective self-evidence creates an opaque screen that prevents attention from reaching out to the Other, the "ever-recommencing awakening in wakefulness itself" facilitates the flow of attention seeking the Other who cannot become my noema or intended target . ${ }^{12}$

To unpack this somewhat cryptic formulation, we may note that the lucidity of self-evidence is nothing but wakefulness, the ego's proximity to and attendance at the site of its concern. But the state of wakefulness tends to sameness, to a hermetically sealed and vigilantly guarded circle of the ego's assimilation to its objects and the objects' assimilation to the ego. That is why the open-ended project of awakening to alterity within the wakefulness of objective self-evidence - a project akin to the kind of "reactivation" that Husserl advocates in The Crisis of European Sciences and Transcendental Phenomenology - necessarily relies on attention that does not stop at "the things themselves" but aims beneath and beyond them. The ever-recommencing - ethical - task of awakening within wakefulness is compatible with the recognition that the dead element in attention is irreducible and that the descent

${ }^{10}$ Freud, Sigmund, "Medusa's Head", in The Standard Edition of the Complete Psychological Works, trans. J. Strachey (London: Hogarth, 1953-66), XVIII, 273. On a psychoanalytically inspired account of "fixed attention as a form of repression", see also Brennan, Teresa, The Interpretation of the Flesh: Freud and Femininity (London and New York: Routledge, 1991), $125 \mathrm{ff}$.

"Levinas, Emmanuel, Discovering Existence with Husserl, cit., p. 156.

12 Ibid., p. 161. 
toward the subjective life and alterity extinguished in self-evidence will have to bear the mark of a work in progress. It is not the purity of psychic life that Levinas wishes to rescue but, if I may paraphrase Nietzsche, the liminal and fragile dawn at high noon when attention to a "what" outstrips itself in attending to a "who."

What had begun as a confirmation and a reiteration of the essential relation of attention to conscious life has now turned into a problematization of this link. Although Levinas still defends the necessity of the subjective moment, on which "the liveliness of life [la vivacite de la vie]" hinges, ${ }^{13}$ he questions the stricture that results from the circumscription of the subject and psychic life to consciousness. "Must the liveliness of life be interpreted on the basis of consciousness?", he asks in an early text on Husserl's phenomenology. ${ }^{14}$ Such questioning does not veer on the side of a vitalistic conception of life, in contrast to the transcendental-phenomenological approach. Instead, it privileges "a material phenomenology of subjective life", ${ }^{15}$ whereby sentience, sensibility, and exposure to the Other precede the operations of intentional consciousness founded upon them.

In thinking about the priority of life over conscious objectivation, Levinas picks up a strand that is already apparent in Husserl's phenomenology, precisely when it comes to the gray area of acts pertaining to what was lived but not regarded as such with attention. Ideas $I$ offers the example of rejoicing to illustrate this point:

The first reflection in rejoicing finds it as actually present now, but not as only now beginning. It is there as continuing to endure, as already lived before, but not looked at. That is, there evidently exists the possibility of tracing the past duration and mode of givenness of what is pleasing, of paying attention to earlier phases in the theoretical course of thought [...]; on the other hand, there exists the possibility of paying attention to the rejoicing advertence to it and, by contrast, to seize upon the lack of regard adverted to it in the phenomenon which has run its course [...] [This] mak[es] even more effectively clear the difference between a rejoicing which is lived, but not regarded [erlebter aber nicht erblickter] and a regarded rejoicing. ${ }^{16}$

The experience that has been lived but not regarded entails a non- or pre-intentional animation, prompting Levinas' recurrent insistence on the need to interrogate, phenomenologically, the non-intentional structures of consciousness. The noetic-noematic correlation of rejoicing and that in which it rejoices may well be lived without my attentional or intentional comportment. Such is the experience I "have" without first taking possession, appropriating,

13 Ibid., p. 160.

14 Ibid., p. 175.

15 Critchley, Simon, Ethics, Politics, Subjectivity: Essays on Derrida, Levinas, and Contemporary French Thought (London \& New York: Verso, 1999),p: 98.

${ }^{16}$ Husserl, Edmund, Ideas I, p. 176. 
or choosing it, the experience, without which no intentional directionality will have been possible. Although Husserl's example of the lived but not regarded rejoicing concerns intra-subjective psychic life, it hints at the basic features of an ethical experience that allows the Other to remain completely Other, without turning him or her into an object of attention. To return to Levinas's question concerning the bases for the liveliness of life, we may observe that attention (or consciousness, generally speaking) loses its exclusive hold on psychic animation and arrives on the scene of the event belatedly, after the experience has already commenced. Non-intentional life undergirds all intentional aspirations of the subject.

It is not by chance that this characterization of non-intentionality is evocative of trauma - in the terms of Cathy Caruth: "unclaimed experience"17 which the subject cannot integrate into her psychic life without, thereby, shattering the psyche as an integral whole. Levinasian ethics, too, is replete with the designations of the Other as a persecutor and of the ethical subject as "the bearing par excellence, [which] bears even the responsibility for the persecuting by the persecutor". ${ }^{18}$ But, in Levinas, ethical traumatism is nothing less than a condition of possibility for having psychic interiority and, indeed, consciousness at all. In the shift from Totality and Infinity to Otherwise than Being, trauma, the breach of psychic interiority by the inappropriable Other, is no longer a matter of attending to an exterior call; on the contrary, the exteriority of the Other is to be sought within the I. To attend to oneself is already to pay attention to the Other. The further one ingresses into the immanence of one's psychic life, the more surely one encounters the absolutely transcendent Other.

This is not to say that experience is essentially inappropriable; thanks to the act of paying attention, second-order experience intentionally repeats the lived but not regarded rejoicing. Husserl invokes attention twice in the brief passage I cited above: the first time, in the context of a reflection that arises in the course of a lived experience that had commenced un-regarded, and the second, in the context of a completed experience viewed retrospectively. Whether or not the feeling of rejoicing is still present in my immediate psychic life, attention enters the phenomenological scene under the banner of theoreticism ("in the theoretical course of thought"), which is the preferred object of criticism Heidegger and Levinas level against Husserl. Consistent with the accusations of theoreticism, it objectivates the ongoing experience and the one that has run its course alike, but this objectivating effect does not require its decoupling from psychic life, in which it is still active, albeit in a derivative way. In fact, on Levinas's reading, attention is synonymous with the

17 Caruth, Cathy, Unclaimed Experience: Trauma, Narrative, History (Baltimore: Johns Hopkins University Press, 1996), passim.

18 Levinas, Emmanuel, Otherwise than Being or Beyond Essence, trans. A. Lingis (The Hague: Martinus Nijhoff, 1981), p. 75. 
gathering of psychic life, the folding of this life into the sphere of subjective interiority. Thus, the question we are facing is whether attention, taken as a figure of psychic gathering, can still pass for an ethical attitude, or, whether, fatefully marked by theoreticism, it objectivates and, hence, violates the Other.

In Totality and Infinity, Levinas introduces the term "dwelling" to draw a parallel between the self-recollection of interiority and attention. The dwelling (la demeure) that isolates the subject from the amorphous exteriority of the element (that is, from the non-possessable milieu, such as the earth, the sea, light, or the city, in which it is immersed) enables, at the same time, the "movement of attention freed from immediate enjoyment [un mouvement de l'attention affranchie de la jouissance immediate]". ${ }^{19}$ Now, one's incapacity to separate oneself from the element (reminiscent of the Freudian "oceanic feeling"), a complete immersion in the city or a nomadic relation to the earth is, for Levinas, both threatening and enjoyable. More importantly for our purposes, it governs the counter-movement of distraction. In the "mystical format of the element", which becomes identical with a space of distraction, I no longer or not yet return to myself, bringing home the fruit I reap from enjoyment. My innocent egoism and loneliness in enjoyment ${ }^{20}$ coincides with my dispersion in the indeterminacy of elemental exteriority and my incapacity to relate attentively to the alterity of the other person. (Nine Talmudic Readings, for instance, implicitly treats the café as the modern embodiment of the elemental, as a space of irresponsibility, distraction, and dissolution of ethical and social bonds.) Dispersion and distraction are dismissed by Levinas as unethical attempts to escape from one's responsibility, which elects, singularizes, and confers identity onto the I who heeds the call of the Other.

Levinas's approach to inattention has much in common with Heidegger's description of inauthenticity, the dispersion of Dasein in the everydayness of its concerns, in which it steeps itself in order to evade the thought of its impending finitude. As in his early works (Existence and Existents; Time and the Other), Levinas conceptually translates the region of transcendence opened up in the anticipation of death into the figure of alterity, and evasion of death into the evasion of one's ethical responsibility to the Other. In both cases, distraction is nothing but a diversion of attention from that which is most crucial toward the mundane. For Levinas, however, everyday concerns can be redeemed so long as they are motivated, in the last instance, by the absolute injunction to come to the assistance of the Other; for Heidegger, they must be nullified, that is, rendered insignificant by anxiety, if Dasein is to pay attention to what truly matters, namely the futurity of its death. In other words, in Levinas's philosophy, distracted absorption in the world of concern may always revert into attention, if my actions are carried out for the sake of Other, who, in a 
famous example, receives the bread, which I have denied myself, interrupting the routine of enjoyment.

Genuine distraction is proper only to a being that has not yet separated itself from the overwhelming exteriority of the element, a being that has not yet staked out the boundaries of its psychic interiority. But, to the extent that all human actions eradiate from the dwelling, or from a separated psychic space, they only feign blindness and inattention:

The lines of meaning traced in matter by activity are immediately charged with equivocations, as though [comme si] action, in pursuing its design, were without regard for exteriority, without attention. ${ }^{21}$

Levinas does not argue that activity comes to pass without regard for the exteriority of the Other who, in the last instance, is the target of attention. Rather, he points out a certain theoretical fiction, whereby I carry out my projects as if I were inattentive and blind to alterity. I do not even explicitly recognize as something other the simple exteriority of matter that serves as a vehicle for the realization of my projected designs. Feigning the attitude of inattention, I take support from the very objects I neglect in the course of my active life, presumably incompatible with an attentive comportment. ${ }^{22}$ The pretense of a heedless immersion in one's affairs, minding one's own "business" from which the fabric of "life" is woven, practically installs an idealist delusion in the subject, who disavows the material substratum, wherein its objectified intentions are etched. And it is this critique of idealism that holds the promise of extending the scope of attention to include the otherness of things alongside the alterity of other human beings. ${ }^{23}$

It remains for us to adumbrate the ethical scope of attention, redressing the possible objectivization of the Other and the exclusion of things. First: Is attention to the Other, indeed, consistent with ethical philosophy or, is distraction a more suitable attitude that respects alterity without turning it into an object? Maurice Blanchot, who so often exhibits a great intellectual affinity to Levinas, parts ways with him precisely on the subject of distraction, writing that

there is the more passive inattention which, beyond any interest or calculation, lets the other be other, leaving them outside of the sphere of violence by which they would be caught, grasped, snared, identified, reduced to sameness. ${ }^{24}$

21

22

23

${ }^{23}$ Here, I can offer only a very schematic account of the alterity of things, deserving of an
ethical approach. For more on this subject, see my The Event of the Thing: Derrida's
Post-Deconstructive Realism (Toronto: University of Toronto Press, 2009).

${ }^{24}$ Blanchot, Maurice, The Writing of the Disaster, trans. A. Smock (Lincoln: University of Nebraska Press, 1986),pp. 53-4. 
In the attitude of inattention, I am not absorbed in my thoughts, narcissistically beholding my own interiority. The "more passive inattention" turns the subject inside out, exposes him or her to alterity, and creates an alliance with the Other in distraction. Blanchot is alluding in this statement to the Levinasian "radical passivity", which, in the words of the latter thinker, is "the way opposed to the imperialism of consciousness." 25 Like passivity, inattention is not tantamount to the purposeful neglect of the Other, but to a refusal to turn her or him into an object of my consciousness, to identify, to reduce to sameness. At the very least, then, it is necessary to differentiate between various kinds of attention and distraction. Whereas the objectivating attention that confirms "the imperialism of consciousness" is as detrimental to the Other as neglectful distraction, passive inattention and attention born from sensibility at the edge of consciousness live up to stringent ethical demands.

Not only does distraction avoid objectivating the Other, but it also enables one to embark on an adventure leading toward radical exteriority and precluding a Hegelian homecoming. According to Totality and Infinity,

[i]t is only in approaching the Other that I attend to myself [ $j$ 'assiste à moi-même] [...] An existence called objective [...] does not express me, but precisely dissimulates me [me dissimule.$^{26}$

Although the products of my activity (a text I have drafted, a painting I have drawn, etc.) are my objective traces, they do not express me because I am not in attendance with them - I do not accompany my works. Only in "being toward the Other" do I skirt the temptation of self-dissimulation. But if this sort of "being-toward...", namely my approach to the Other, mediates my attention to myself, then it is unethical, given that my aspiration toward him or her turned out to be not asymmetrical and unidirectional, but a detour in my self-relation. Against this theoretical backdrop, the virtue of the distracted dissimulation of the self is that it escapes the temptation of a homecoming and self-recuperation by means of the Other.

Second: Is attention to things necessarily shallow, superficial, or, worse still, unethical? Engaging with Levinas's philosophy in a text as early as "Violence and Metaphysics", Derrida observes the injustice of excluding thinghood from the domain of the Other. He notes that what

the things share here with others, is that something within them too is always hidden, and is indicated only by anticipation, analogy, and appresentation [que les choses partagent ici avec autrui, c'est que quelque chose en elles se cache aussi toujours et ne s'indique que par anticipation, analogie et apprésentation]. ${ }^{27}$

${ }^{25}$ Levinas, Emmanuel, Otherwise Than Being, cit., p. 92.

26 Levinas, Emmanuel, Totality and Infinity, cit., pp. 178/194.

27 Derrida, Jacques, Writing and Difference, trans. A. Bass (Chicago: University of Chicago Press, 1980), 124/182. 
Because both things and human others are transcendent to my consciousness, because they equally partake of this inaccessible, secret, non-psychic interiority infinitely deferred in time and space, Derrida levels a criticism against Levinasian "transcendental violence" that, despite Levinas's own philosophical commitments, circumscribes the field of alterity to the otherness of another person. This criticism is essentially Husserlian, since it brings to mind those mental acts that are "directed to something transcendent", be it another ego or a thing. "Such", Husserl writes, "are all acts directed to essences or to intentive mental processes belonging to other Egos with other streams of mental processes, and likewise all acts directed to physical things or to realities of whatever sort." ${ }^{28}$ In light of the deconstructive questioning, which renders porous the boundaries separating the "who" and the "what", especially when it comes to thinghood, the reduction to the ethical, which Levinas sketches out in his discussion of attention, needs to be further complicated.

This is not to say that, mutatis mutandis, the Other is reducible to a thing, let alone to a transcendental Thing, or a formal condition of possibility for subject-formation. The Other is both a thing and not a thing, or, as Derrida puts it,

the other as res is simultaneously less other (not absolutely other) and less 'the same' than I [l'autre comme res est à la fois moins autre (non absolument autre) et moins 'le même'que moi]. ${ }^{29}$

Less other than another person, the alterity of the thing might provide the materials for the operations and manipulations of consciousness. More other, or, in Derrida's words, "less "the same",", it is not another "I", but something foreign to the formal structure of consciousness which, in each case, is filled with an infinite variety of heterogeneous contents, however inaccessible they are from the standpoint of a single subject. From a strictly phenomenological perspective, the quality common to Others and to things is that, unlike objects, they do not -indeed, cannot- expose themselves to me in their entirety, no matter how attentive I am toward them. I can attend to either of them only at the limits of attention, having loosened the constraints of objectivation. Only attention paid at the limit, to the limit of what one can attend to, deserves the appellation "ethical".

The point of the above exercise in immanent criticism was to allow Levinas's thought to live up to the high ethical and philosophical demands it imposes on us and, certainly, by the same token, on itself. It is not enough to set reduction on the infinite path to the absolutely Other, if this Other is a priori determined as a "who" and if attention, which overlaps with intentionality (i.e., with the very being of consciousness), is selected as the exclusive mode 
of approaching the Other. Upon adumbrating its scope, we cannot help but highlight the strengths of Levinas's theory that diagnoses the constitutive torsions and tensions at the heart of attention, which is divided between autonomy and heteronomy, freedom and responsibility, the I and the Other, interiority and exteriority. Such internal splits and fissures in attention have the potential of rendering it ethical, that is, incapable of dominating that to which, or the one to whom, it is extended.

\begin{abstract}
In his rather fragmentary theory of attention, Emmanuel Levinas draws inspiration from phenomenology, while endeavoring to furnish it with an ethical foundation. On the one hand, he assigns to attention a crucial role coextensive with intentionality (the idea that, in each case, consciousness is conscious of, or directed toward, something). On the other hand, he mobilizes the methodology of reduction for the purpose of uncovering an ethical substratum of experience in the relation to the Other, which is deeper still than the life of consciousness it animates. Husserlian reduction is not radical enough for Levinas's philosophical taste, since it fails to recognize that this life comes into being thanks to the appeal emanating from the Other, whose calling out to me forces me to pay attention, even when it seems that I am attending only to inanimate things. The ethical relation to the Other lies not only at the bottom of all social and political structures, but also at the source of consciousness and of its attentive directedness to that of which it is conscious. Before I am able to intend or to attend to anything whatsoever, I am targeted by the Other, who reverses the movement of intentionality and, at once, breaches and founds my psychic interiority.
\end{abstract}


